\title{
An Investigation of the Relationship Between Level of Aggression, Communication Skills and Computer Game Addiction Among Secondary School Students: Structural Equation Modelling
}

\author{
Rana Demircioğlu \\ Guide and Psychological Counselor \\ E-mail: ranademircioglu@gmail.com \\ Ali Haydar ŞAR* \\ Educational Sciences, Faculty of Education, Sakarya University, Sakarya, Turkey \\ E-mail: asar@sakarya.edu.tr
}

\begin{abstract}
Computer game addiction is a widespread problem, especially among children and adolescents. In order to prevent or minimize computer game addictions, it is substantial to understand why they became addicted to computer games. The reasons behind computer game addiction will also direct prospective interventions. Therefore, the research is based on these variables, considering that communication skills and aggression may cause computer game addiction. The research aims to examine the relationship between computer game addiction and aggression levels and communication skills in secondary school students by using structural equation modeling. According to the constructed structural equation model, it was expected that students' communication skills would be effective on aggression in computer game addictions. The method of the research was determined as a correlational pattern from quantitative research methods. The sample of the study consists of 1123 secondary school students (5th, 6th, 7th and 8th grade) who are studying in six public schools in the Serdivan, Sakarya in the 2019-2020 academic year. Data from students were collected using personal information form, Computer Game Addiction Scale for Children, Aggression Scale, and Communication Skills Evaluation Scale. The collected data were analyzed with SPSS 22.0 and AMOS. As a result of the KolmogorovSmirnov test, the data showed normal distribution. Therefore, parametric tests (independent sample t-test, ANOVA) were used. In order to find answers to the problem sentence of the research, firstly, the relationship between the variables of the research was analyzed in the SPSS. Then, the structural equation model was tested in AMOS. As a result of the analysis, it was seen that the middle school students who participated in the research had low computer game addiction levels and their communication skills affected computer game addiction through aggression. Also, according to the findings, communication skills directly affected the aggression; aggression directly affected computer game addiction.
\end{abstract}

Keywords: Computer game addiction, Aggression, Communication skills, Structural Equation Modeling

DOI: $10.7176 / \mathrm{JEP} / 12-26-01$

Publication date:September $30^{\text {th }} 2021$

\section{Introduction}

Although there are many technological tools available today, computers are of particular importance. Computers have become a part of daily life at home and outside the home, with or without internet connection, for the purpose of gaming, working, communication, sharing, education, and having leisure time (Horzum et al., 2008). The use of computers for gaming is becoming more and more common (Yalçın Irmak \& Erdoğan, 2016). According to research, almost every youngster regardless of gender, age, or psychosocial status plays computer games (Allahverdipour, Bazargan, Farhadinasab, \& Moeini, 2010). It is found that most of the students in schools, regardless of the level of education, play computer games. Also, the opinions of teachers and psychological counselors working in different schools support this observation result. Today, the games that children play on the streets or at home, with their friends or alone are transferred to computers. Thus it can be said that screens have become friends of children. Horzum (2011) states that with technology, outdoor games have been replaced by virtual indoor games.

However, computers are not just a game tool; but a tool that provides fast, easy, and accurate access to information which helps in problem-solving (Horzum et al., 2008). In addition, this misperception causes schoolage children to misuse computers and consequently suffer from physical, mental, emotional, and social problems (Küçükturan, 2018). The problems that computer games cause for individuals have been a subject for many studies, and the most important one of the problems that arises is considered to be addictions (Horzum, Güngören, \& Demir Kaymak, 2018).

Computer game addiction refers to the long-term, out of control and detrimental use of computer games (Şahin \& Tuğrul, 2012). Individuals generally start playing video games to have fun and spend some leisure time, 
yet eventually become addicted to the games (Akçayır, 2013). It can be asserted that computer game addiction develops with an insidious course during the process and is the last point the individual reaches. When individuals get addicted to gaming, video games become their whole lives (Horzum, 2011). One of the inevitable results is that individuals who spend most of their time playing video games may experience many problems in multiple different areas of their lives. Computer game addiction brings along academic failures, family problems, physical and mental disorders and causes the individual to disconnect from his/her social life (Eroğlu, 2009).

The problematic lifestyle generated by computer game addiction causes several concerns. For instance, a systematic review of computer game addiction impact on adolescent physical health concluded that obesity, back pain, neck pain, joint muscle, eyesight problem, hearing problem, and physical inactivity were among undesired detrimental effects of game addiction among adolescents (Aziz, Nordin, Abdulkadir, \& Salih, 2021). Computer game addiction is quite a significant problem that primarily parents, teachers, and school counselors should pay attention to (Şahin \& Tuğrul, 2012). For this very reason, technology addiction has been included in school psychological counseling and guidance programs within the scope of Addiction Prevention Training Program of Turkey (TBM) project developed by the Turkish Green Crescent Society (2020). In the scope of the project, informative events are organized for students, teachers, and parents. In addition, parents seem to have a prominent role in preventing gaming addiction, and the arrangements they can make in the child's life are mentioned in various studies (ASPB, 2017; Seay \& Kraut, 2007; Tarhan \& Nurmedov, 2017). However, these intervention methods have a possibility of remaining superficial due to being based on either information delivery or external intervention. According to Wood (2008), gaming addiction is an expression of the problems of an individual. Therefore, taking therapy support for the problems experienced by these individuals is well expected to be effective for healing gaming addiction.

In the scope of every addiction, various factors lead individuals to it (BATEM, 2020). In the case of gaming addiction, the incentives for playing games are effective in developing addiction (Seay \& Kraut, 2007). According to several pieces of research, it was concluded that individuals mostly play games to have fun, spend their spare time and relax (Akçayır, 2013; Aydoğdu \& Karaaslan, 2015; Çelik \& Ulusoy, 2019; Grüsser, Thalemann, Albrecht \& Thalemann, 2005; Seay \& Kraut, 2007; Tutgun Ünal, İnan, Kaya, Frrat, Güzelbaba and Bahadır, 2013). Regarding these reasons, various inferences can be made about the individuals who are addicted to computer games.

Çelik and Ulusoy (2019) stated that students find playing computer games more fun than playing with their friends, and they prefer computer games to other activities. Thereby, individuals can play computer games for a more extended time, which they think is more fun.

Not having peers or adults with whom one can have fun and spend time together may be a factor for extreme gaming. Concerning the relationships with the family, it is stated that an individual can become addicted to gaming due to loneliness caused by a lack of communication within the family (Aksakall1, 2017). Furthermore, being away from friends or being ostracized by friends and becoming lonely might be effective in leading an individual towards playing computer games. It is stated that individuals who become lonely play more games (Horzum et al., 2018).

Individuals can play computer games to relieve stress or get relaxed. Seay and Kraut (2007) suggested that games have a relaxing effect on individuals and reduce their stress and anxiety. Individuals may feel tension due to the stress of daily life, the problems they experience in general, or their personality structure. It is argued that individuals exposed to family conflicts and feel inadequate in solving those issues and uneasy can use games as a means of relief (Aksakallı, 2017). Likewise, computer games have a calming effect on tense individuals (Griffiths, 1993 as cited in Griffiths \& Dancaster, 1995; Tarhan \& Nurmedov, 2017). Kestenbaum and Weinstein (1985) conducted an experimental study on the relationship between extreme video gaming and personality and psychopathological factors. According to the study, extreme gaming helps individuals to discharge aggression. Thus, it can be inferred that aggressive individuals may play computer games more than others.

Based on these researches and inferences, the factors that games are seen as fun and distracting, and lack of communication and aggression can be asserted to be effective in becoming addicted to computer games.

First of all, regardless of education level, students are observed to spend enormous time on computer games, talk about computer games with friends at school, and compete in computer games as groups. This situation may raise the suspicion of gaming addiction for students. Furthermore, the application reasons of students, parents, and teachers to the guidance service are emphasized in order to comprehend the school climate and student, teacher, and parent profiles. The students often mentioned the quarrels and resentments caused by misunderstandings, peers harming them or their belongings, and saying bad words. On the other hand, teachers often suffer from students' rude behaviors towards each other, student fights, disrespectful attitudes towards teachers, and failure to fulfill their responsibilities. Moreover, parents complain about not getting their children to do homework, stop playing computer games, and the children's aggressive behaviors toward their parents and siblings. These kinds of applications to the counseling service firstly bring to mind the concept of peer bullying. Peer bullying, which has been often included in school psychological counseling and guidance programs in 
recent years, is observed among peers or youngsters who are close in age with a power imbalance; and is defined as the acts of the powerful one with the intention of disturbing or harming the powerless one (Çankaya, 2011). However, this concept does not cover the problems that arise between student-teacher and student-family relations. Therefore, another concept that can describe these detrimental and problematic behaviors was inquired and finally focused on the concept of aggression. Aggression is defined as the destructive behavior of an individual in order to cause physical or mental damage to others (Abay \& Tuğlu, 2000). Balc1 and Beldağ (2019) state that aggressive behaviors in schools have increased in recent years. In addition, poor communication skills are considered a contributing factor of aggressive behavior for individuals (Kurtyılmaz, 2005). As a result, it can be inferred that lack of communication skills and aggressive behaviors are common risks for students.

Amongst gaming addiction research, studies on adolescents particularly draw attention. According to Tarhan and Nurmedov's (2017) research, adolescents are a risk group for developing gaming addiction, as in other types of addiction. Hauge and Gentile (2003) state that gaming addiction is a substantial problem for adolescents. Griffiths (2008) argues that computer game addiction is one of the problematic behaviors observed in adolescents. Much research shows that computer games are played mainly by adolescents (Emre, 2020; Griffiths, Davies, \& Chapel, 2004; Tarhan \& Nurmedov, 2017). Likewise, the opinions of school psychological counselors and teachers working in primary, secondary, and high schools are in accordance with these studies.

Considering the education levels, adolescence coincides with the secondary and high school levels. Besides, the secondary school period is crucial as it includes both puberty and adolescence. Puberty is the transition period from childhood to adolescence (Ögel, 2002). Furthermore, during this period, if youngsters cannot identify themselves with one of the concepts of child or adolescent, this may lead them to have complications and troubles in interpersonal relationships. Also, since the individuals who pass puberty and reach adolescence cannot feel like fully grown adults, these problems can continue to be present. This situation is able to cause aggressive behaviors in individuals. Eroğlu (2009) also states that adolescents have a more aggressive attitude due to their efforts to acquire an identity. In both periods, the family begins to stay in the background for adolescents, and peer groups gain more and more importance. Adolescents' conflicts with their families due to the feelings of not being understood and their desire to have a place in peer groups and establish relationships (Ögel, 2002) shows that communication skills are essential for youngsters in this period.

The purpose and significance of the research

The purpose of the study is to examine the relationship between computer game addiction and aggression levels and communication skills of secondary school students in terms of various variables using structural equation modeling.

In line with this model, the hypotheses of the research are as follows:

H1: Secondary school students' communication skills directly affect aggression.

H2: Aggression directly affects computer game addiction in secondary school students.

H3: Communication skills indirectly affect computer game addiction in secondary school students.

This work is;

- Current, since adolescents are more interested in computer games and are considered as a risk group for gaming addiction,

- Necessary since that the studies on computer game addiction do not show the cause-effect relationship and this study shows the causes of gaming addiction,

- Novel, since there is no other study examining the relationship between gaming addiction and communication skills with aggression levels using structural equation modeling,

- Functional, because the effect of communication skills and aggression on gaming addiction can be a source for guidance activities that help individuals improve their communication skills and control their aggressive behavior to prevent computer game addiction and guide future studies.

\section{Methods}

\section{Methodology of the research}

The method of the research was determined as the correlational design, one of the quantitative research methods. Population and sample of the research

The population of the research consists of approximately 3000 people. On the other hand, the sample consists of a total of 1144 participants, taking into account the .03 deviation from the population of 3000 people and .01 margin of error. Criterion sampling from purposive sampling methods is used in the selection of the sample from the population. Secondary school grade levels of 5th, 6th, 7th, and 8th grades were taken as criteria, and 300 students were selected from each grade.

\section{Analysis of data}

First of all, after the data was transferred to the SPSS 22.0 package program, it was checked for incorrect entries and missing data. Then the normality of the data, which is one of the assumptions of the comparison tests, was checked. According to the results, the variables were normally distributed for the samples. Hence, parametric 
methods were used to analyze the problems of this research. Since the means of two sample groups were compared within the scope of the study, independent samples t-test was used. Moreover, the analysis of variance (ANOVA) for independent samples was applied to compare more than two samples.

\section{Results}

1- "Are computer game addictions, aggression levels, and communication skills of secondary school students related?"

Table 1. The relationship between total scores of communication skills, aggression, and computer game addiction

\begin{tabular}{|l|l|l|l|}
\hline & Communication Skills & Aggression & Gaming Addiction \\
\hline Communication Skills & - & & \\
\hline Aggression & $-0.178^{* *}$ & - & \\
\hline Gaming Addiction & $-0.147 * *$ & $0.413 * *$ & - \\
\hline
\end{tabular}

** Correlation is significant at the $\mathrm{p}<0.01$ level.

According to Table 1, there is a negative, very weak, and significant $(\mathrm{r}=-0.178, \mathrm{p}<0.01)$ relationship between total score of communication skills and total score of aggression; and a negative, very weak and significant $(\mathrm{r}=-0.148, \mathrm{p}<0.01)$ relationship between total score of communication skills and total score of computer game addiction; also a positive, moderate and significant $(\mathrm{r}=0.413, \mathrm{p}<0.01)$ relationship between total score of aggression and total score of computer game addiction.

2- Findings regarding sub-problems 2, 3, and 4:

In this study, a two-stage modeling procedure was applied. Within this scope, three latent variables, namely communication skills (ILT_BEC), aggression (SLDRGNLK), and computer game addiction (OYN_BAG), and also twenty-three observe $\bar{d}$ variables (IL1, IL2, ..., IL23) for communication skills and fifteen observed variables (SL1, IL23) for aggression. SL2, .., SL15) and twenty-one observed variables (OB1, OB2, .., OB21) for computer game addiction were included. Using the variables above, the measurement model was established and analyzed before forming the structural model. According to the results of the analysis, the fit indices of the measurement model were $\chi 2=4882.570, \mathrm{p}=.000, \mathrm{sd}=1640, \chi 2 / \mathrm{sd}=2.98, \mathrm{GFI}=0.87, \mathrm{NFI}=0.97, \mathrm{CFI}=0.97$, $\mathrm{IFI}=0.97, \mathrm{RFI}=0.95, \mathrm{AGFI}=0.86, \mathrm{RMSEA}=0.042, \mathrm{SRMR}=0.047$. The correlation coefficients obtained for the latent variables of communication skills, aggression, and computer game addiction due to the measurement model are presented in Table 2.

Table 2. The relationship between latent variables of communication skills, aggression, and computer game addiction

\begin{tabular}{|l|l|l|l|}
\hline & Communication Skills & Aggression & Gaming Addiction \\
\hline Communication Skills & - & & \\
\hline Aggression & $-0.220 *$ & - & \\
\hline Gaming Addiction & $-0.150 *$ & $0.450 *$ & - \\
\hline
\end{tabular}

* Correlation is significant at the $\mathrm{p}<0.05$ level.

The correlation coefficients obtained for latent variables in Table 2 shows that there was a negative, weak, and significant $(\mathrm{r}=-0.220, \mathrm{p}<0.05)$ relationship between communication skills and aggression; and there is a negative, very weak, and significant $(\mathrm{r}=-0.150, \mathrm{p}<0.05)$ relationship between communication skills and computer game addiction; and also a positive, moderate and significant $(r=0.450, p<0.05)$ relationship between aggression and computer game addiction.

After testing the measurement model, the testing of the structural model of the two-stage modeling procedure was initiated. Three different models were established within this scope between communication skills, aggression, and computer game addiction, respectively.

Model I: Consists of Communication Skills and Computer Game Addiction

Model II: Consists of Communication Skills, Aggression and Computer Game Addiction

Model III: Consists of Communication Skills and Computer Game Addiction

Mediated by Aggression 


\section{First model:}

In this model, communication skills and computer game addiction are both included. The model was analyzed and the fit indices were calculated as $\chi 2=2453.760, \mathrm{p}=.000, \mathrm{sd}=895, \chi 2 / \mathrm{sd}=2.74, \mathrm{GFI}=0.91$, NFI $=0.96$, $\mathrm{CFI}=0.97, \mathrm{IFI}=0.97, \mathrm{RFI}=0.96, \mathrm{AGFI}=0.90, \mathrm{RMSEA}=0.039, \mathrm{SRMR}=0.041$. Comparing the fit values obtained for this first model with the determined critical values, it can be concluded that fit indices are in the range of good and acceptable fit, and the tested first model ensures model-data fit. The path diagram containing the standardized path coefficients for the first model is presented in Figure 1. In addition, the unstandardized and standardized path coefficients obtained for the first model and the $t$ values of these path coefficients are also presented in Table 3.

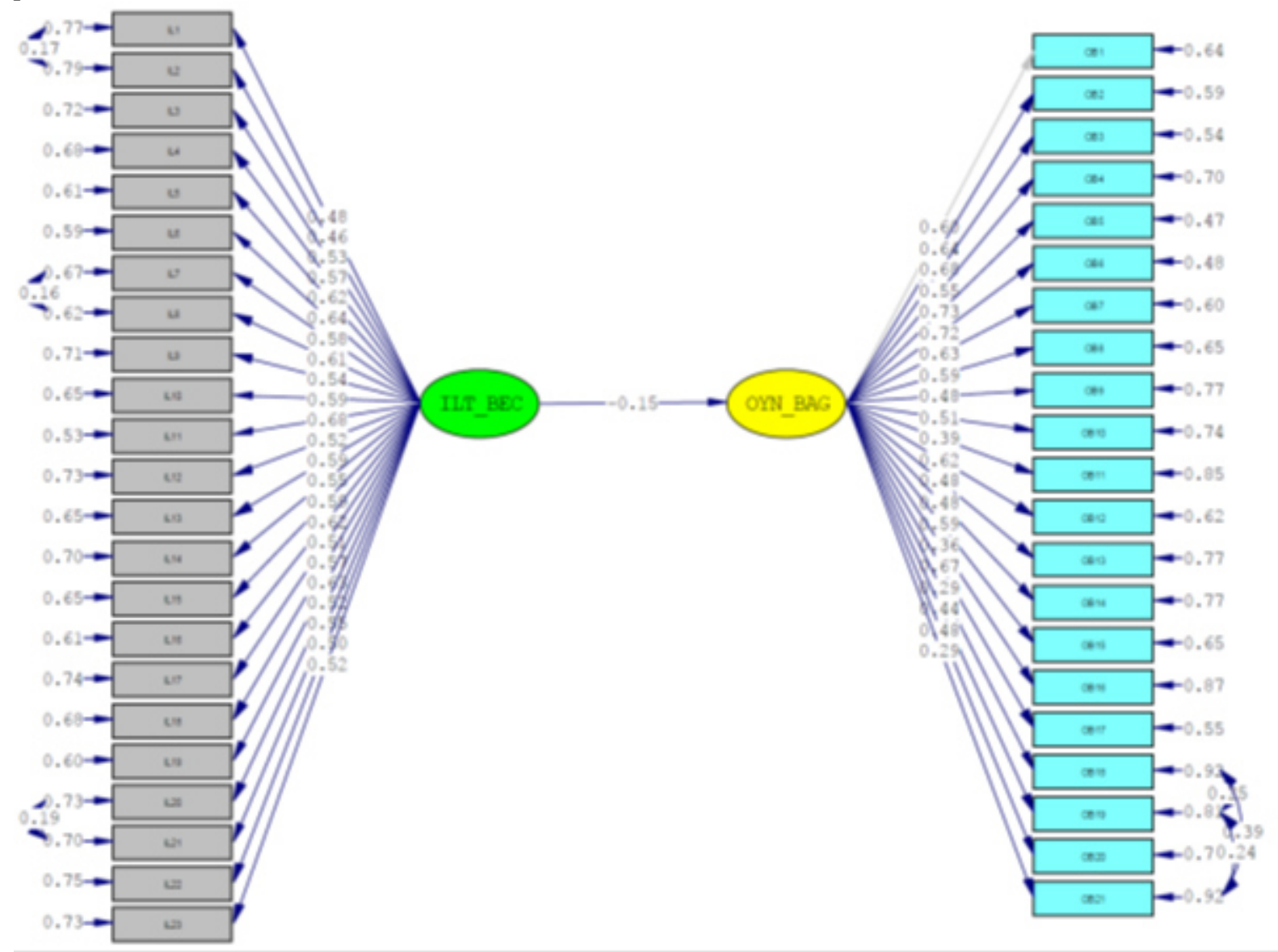

Figure 1. Standardized path coefficients calculated for the first model

Table 3. Results of path coefficients for the first model

\begin{tabular}{|l|l|l|l|}
\hline Direct Effect & Unstandardized Coefficient & Standardized Coefficient $-\beta$ & $\mathrm{t}$ \\
\hline ILT_BEC $\rightarrow$ OYN_BAG & -0.16 & -0.15 & -4.63 \\
\hline
\end{tabular}

Correlation is significant at the $\mathrm{p}<0.05$ level.

According to Table 3, it can be interpreted that communication skills have a direct and significant $(\beta=-0.15, \mathrm{t}=$ $4.63, \mathrm{p}<0.05)$ effect on computer game addiction; that is as a predictor. However, communication skills explain $2.4 \%$ of computer game addiction.

\section{Second model:}

In this model, communication skills, aggression, and computer game addiction are included, and these variables affect each other, respectively. This model was analyzed and the fit indices were calculated as $\chi 2=4880.930, \mathrm{p}$ $=.000, \mathrm{sd}=1641, \chi 2 / \mathrm{sd}=2.97, \mathrm{GFI}=0.87, \mathrm{NFI}=0.95, \mathrm{CFI}=0.97, \mathrm{IFI}=0.97, \mathrm{RFI}=0.95, \mathrm{AGFI}=0.86, \mathrm{RMSEA}=$ $0.042, \mathrm{SRMR}=0.059$. Comparing these fit values obtained for the second model with the determined critical values, the fit indices fall in the range of good and acceptable fit, and the tested model ensures model-data fit. The path diagram containing the standardized path coefficients for the second model is presented in Figure 2. In addition, the unstandardized and standardized path coefficients obtained for the second model and the $t$ values of these path coefficients are also presented in Table 4. 


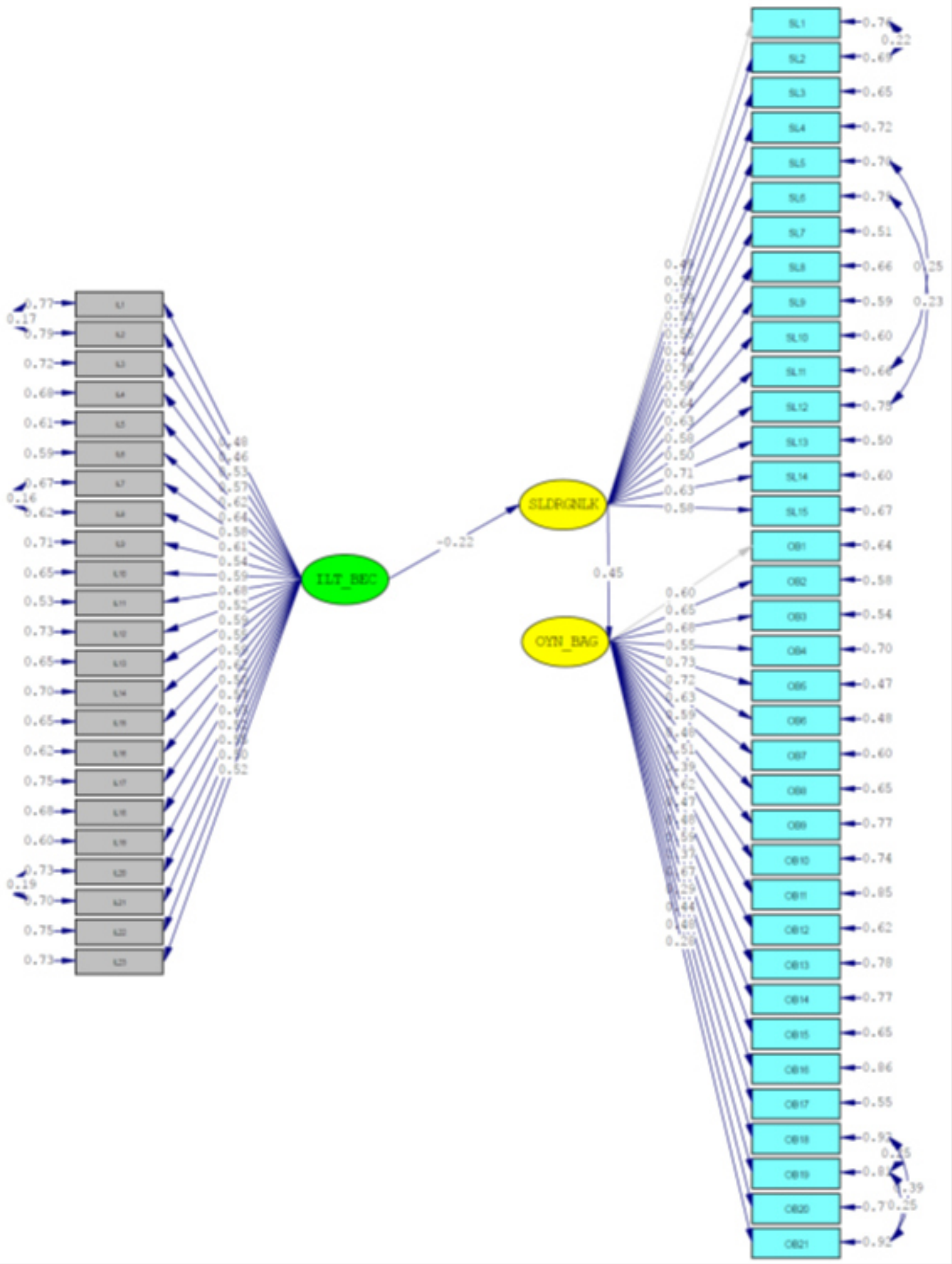

Figure 2. Standardized path coefficients calculated for the second model Table 4. Results of path coefficients for the second model

\begin{tabular}{|l|l|l|l|}
\hline Direct Effect & Unstandardized Coefficient & Standardized Coefficient $-\beta$ & $\mathrm{t}$ \\
\hline ILT_BEC $\rightarrow$ SLDRGNLK & -0.21 & $-0.22^{*}$ & -6.33 \\
\hline SLDRGNLK $\rightarrow$ OYN_BAG & 0.49 & $0.45^{*}$ & 10.41 \\
\hline
\end{tabular}

Correlation is significant at the $\mathrm{p}<0.05$ level. 
Examining Table 4, it can be inferred that communication skills have a direct and significant $(\beta=-0.21, \mathrm{t}=-6.33$, $\mathrm{p}<0.05)$ effect on aggression, and aggression has a direct and significant $(\beta=0.45, \mathrm{t}=10.41, \mathrm{p}<0.05)$ effect on computer game addiction, or is a predictor of it. However, communication skills explain $4.9 \%$ of aggression, and aggression explains $20 \%$ of computer game addiction.

\section{Third model:}

This is a model in which communication skills, computer game addiction, and mediation of aggression are included and affect each other. This model was analyzed and the fit indices were calculated as $\chi 2=4882.570, p$ $=.000, \mathrm{sd}=1640, \chi 2 / \mathrm{sd}=2.98, \mathrm{GFI}=0.87, \mathrm{NFI}=0.97, \mathrm{CFI}=0.97, \mathrm{IFI}=0.97, \mathrm{RFI}=0.95, \mathrm{AGFI}=0.86, \mathrm{RMSEA}=$ $0.042, \mathrm{SRMR}=0.047$. Comparing the fit values obtained for the third model with the critical values of SEM, the fit indices are in the range of good and acceptable fit, and the tested structural model provides model-data fit. The path diagram containing the standardized path coefficients for the third model is presented in Figure 3 . In addition, the non-standardized and standardized path coefficients obtained for the structural model and the $t$ values of these path coefficients are also presented in Table 5.

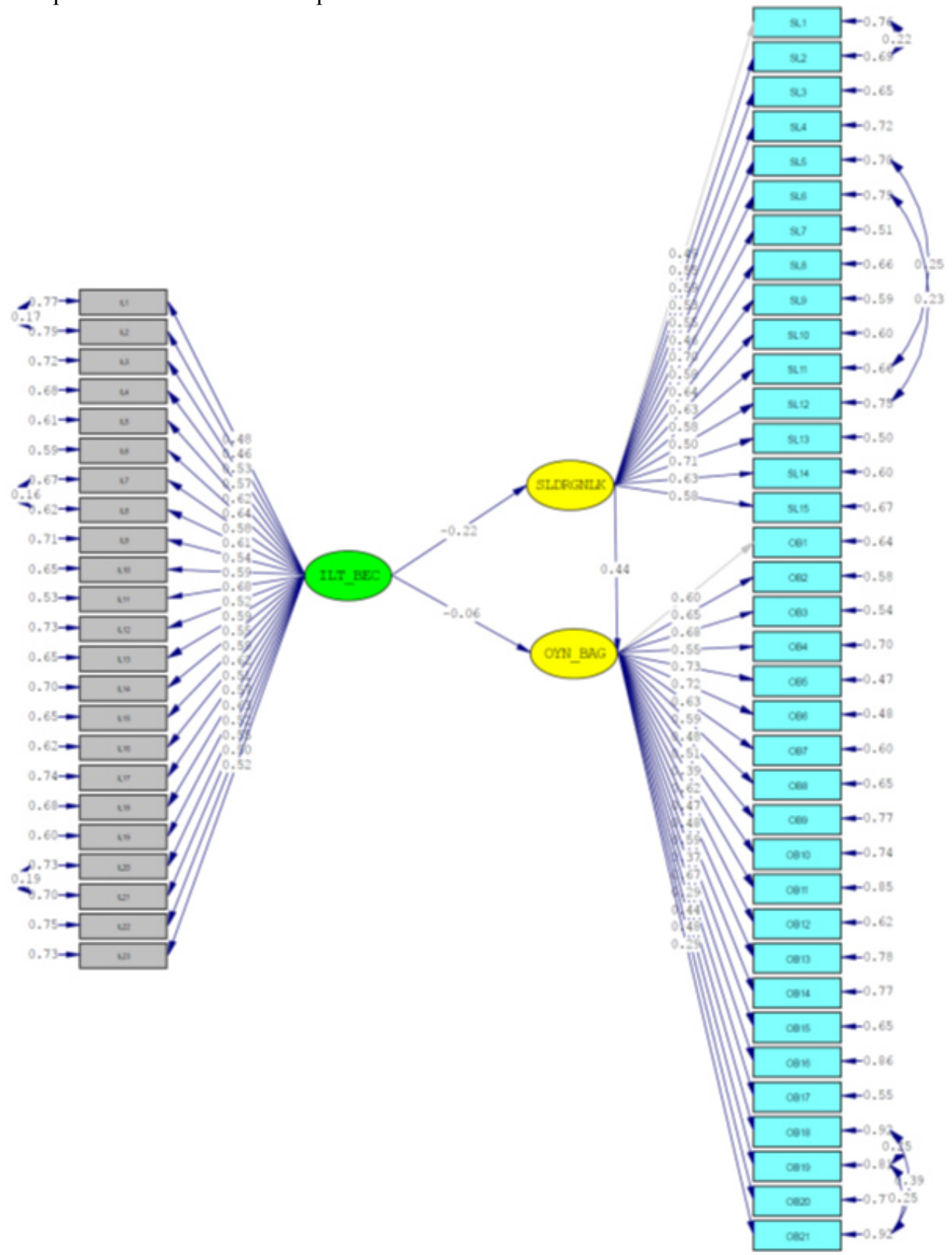

Figure 3. Standardized path coefficients calculated for the structural model 
Table 5. Results of path coefficients for the third model

\begin{tabular}{|l|l|l|l|}
\hline Direct Effect & Unstandardized Coefficient & Standardized Coefficient $-\beta$ & $\mathrm{t}$ \\
\hline ILT_BEC $\rightarrow$ SLDRGNLK & -0.20 & $-0.22^{*}$ & -6.23 \\
\hline SLDRGNLK $\rightarrow$ OYN_BAG & 0.47 & $0.44^{*}$ & 10.10 \\
\hline ILT_BEC $\rightarrow$ OYN_BAG & -0.06 & -0.06 & -1.88 \\
\hline
\end{tabular}

Correlation is significant at the $\mathrm{p}<0.05$ level.

According to Table 5, it can be interpreted that communication skills have a direct and significant $(\beta=-0.22$, $\mathrm{t}=-6.23, \mathrm{p}<0.05)$ effect on aggression, and aggression have a direct and significant $(\beta=0.44, \mathrm{t}=10.10, \mathrm{p}<0.05)$ effect on computer game addiction, that is, as a predictor. However, communication skills have no significant ( $\beta$ $=-0.66, \mathrm{t}=-1.88, \mathrm{p}>0.05)$ effect on computer game addiction. In addition, communication skills explain $4.7 \%$ of aggression, and communication skills and aggression together explain $21 \%$ of computer game addiction. Equations established for the third model are as following: Game Addiction $=0.47 \mathrm{x}$ Aggression $+(-0.58) \mathrm{x}$ Communication Skills, Aggression $=(-0.20)$ x Communication Skills .

The non-significant $(\beta=-0.66, \mathrm{t}=-1.88, \mathrm{p}>0.05)$ effect of communication skills on computer game addiction shows that the aggression variable is a full mediator between these two variables.

\section{Discussion}

"Are computer game addictions, aggression levels, and communication skills of secondary school students related?"

According to the results of this study, there is a negative relationship between communication skills and aggression of secondary school students, and a negative relationship between communication skills and computer game addiction, and a positive and significant relationship between aggression and computer game addiction.

"Do the communication skills of secondary school students directly affect their aggression levels?" (ModelI)

According to the findings, the communication skills of secondary school students directly affect their aggression levels. As a result of the analysis, communication skills predict aggression for secondary school students.

Ayas (2012) states that since humans are social beings, they have to communicate with other people; otherwise, they would have problems. According to the findings of this study, it can be argued that one of these problems is aggression. In another study, Dumas, Blechman, and Prinz (1994) claim that individuals' inadequate communication skills are effective in the development and maintenance of aggressive behaviors. Similarly, it is stated that individuals do not know how to communicate with people due to their inadequate communication skills (Ersanlı \& Balc1, 1998). Moreover, Yücel (2002) argues that aggression arises due to the disappointments experienced by the individual during communications with others. Therefore, the views mentioned above can be ways for explaining this finding.

The causal relationship between communication skills and aggression can also be explained in the light of the frustration-aggression hypothesis, social learning theory, and cognitive theory. According to the frustrationaggression hypothesis, the obstacles faced by the individual while meeting any of his needs cause aggressive behaviors (Dervent, 2007). Continuing this point of view, an individual who does not have sufficient communication skills may experience a state of frustration, and thereby, her/his aggression would increase since she/he could not express her/his wishes and needs in a healthy way. According to the social learning theory, the individual learns all behaviors under the influence of the environment (Eroğlu, 2009). Therefore, the communication skills of children who grow up in families where communication within the family is disconnected and insufficient and ineffective can also be insufficient. The child, who witnesses such aggressive discourses and behaviors instead of openness and honesty in communication within the family, may eventually resort to the same methods in his interactions with his environment. In conclusion, the facts that the aggressive attitudes of the family cause aggression in the child (Erdoğdu \& Oto, 2004) and that the communication skills of the individuals who are exposed to violence in the family are found to be lower than those who are not exposed to violence (Koç et al., 2015) supports the findings of our study. According to cognitive theory, aggression is related to how the individual perceives and interprets the other (Berkowitz and Allen 1967 as cited in Köksal, 1991). Communication skills include active listening (Aydın, 2012). Active listening is an individual's willingness to listen and respond appropriately (McWhirter \& Voltan Acar, 2000). Considering all this information, a person with insufficient active listening skills and therefore inadequate communication skills 
might exhibit aggressive behaviors according to cognitive theory. In addition, O'Rourke and Worzbyt (1996) also state that individuals who interpret human behavior as prejudiced and hostile are more aggressive.

Regarding previous studies, Kurtyılmaz (2005) revealed that communication skills predict the aggression levels of university students. Thus, this also shows similar findings to the findings we obtained. Based on this research, it can be argued that communication skills play an essential role in aggression regardless of age variable.

"Does the aggression levels of secondary school students directly affect their computer game addiction?" (Model-II)

According to the findings, secondary school students' aggression levels are a direct and significant predictor of their computer game addiction. Lemmens et al. (2006) state that aggressive individuals tend to play violent video games in support of this situation.

Aggression affects gaming addiction in two forms. Firstly, aggressive individuals may become attracted to games, mainly violent ones, because of their aggressive tendencies. They would enjoy playing games that they are interested in, which may lead to computer game addiction due to long-term gaming behavior. Recently, most of the popular games are violent. The frequent repetition and rewarding of aggressive behaviors in violent games (Akçayır, 2013), and the fact that the violence in games is very close to reality (Setzer \& Ducket, 1993), and the active and aggressive behaviors performed by the player while gaming (Dill \& Dill, 1998), all these are able to make the player feel the same emotions that she/he feels when she/he performs aggressive behaviors in real life. Therefore, aggressive individuals might become interested in these games. Griffiths et al. (2004) state that adolescents prefer playing games more because of their violent content. Also, it is stated that a game that attracts the individual's attention motivates the individual greatly and creates a desire to play again and again (Horzum, 2011). Similarly, it is claimed that the attractiveness of games causes addiction (Griffiths \& Dancaster, 1995 as cited in Griffiths 1993). In addition, individuals addicted to computer games play video games for a more extended time to get more pleasure (Horzum et al., 2008). Hence, these studies may support the hypothesis that aggression causes computer game addiction. Here, the reason that pushes aggressive individuals to gaming addiction is being attracted to games due to aggressive tendencies.

The effect of aggression on gaming addiction can also occur as follows: Aggressive individuals may try to relieve the tension through gaming. They might want to play more games if they feel relieved by playing, which can eventually cause gaming addiction. The study conducted by Kestenbaum and Weinstein (1985) can be put forward to support this theory. Kestenbaum and Weinstein (1985) state that excessive gaming helps individuals to discharge their aggression. Likewise, Ferguson (2007) asserts that violent games can alleviate aggression in individuals. Many studies support that individuals addicted to computer games can play games as a relaxation tool (Aydoğdu Karaaslan, 2015). According to Griffiths (1993), choosing computer games as a relaxation method leads individuals to addiction (as cited in Griffiths \& Dancaster, 1995). Another study by Graybill, Kirsch and Esselman (1985) shows that violent video games elicit aggressive impulses in individuals in a socially acceptable way, and aggressive individuals become more positive and less aggressive by playing violent video games. Also, according to this study, individuals act aggressively by directing the game character; thus, they perform aggressive behaviors that they cannot perform in real life in the virtual world. Therefore, it can be argued that the individual reveals her/his aggression by identifying herself/himself with a game character.

Regarding the relevant literature, the study conducted by Kinay (2019) shows that anger, which is a subdimension of the aggression scale, explains gaming addiction; therefore, aggression affects gaming addiction. Studies of Jeong et al. (2016) and Kim and Kwon (2004) can also support our findings. These studies and our findings suggest that aggression can predict gaming addiction, regardless of the type. However, the scarcity of studies in terms of quantity in this field undermines the validity of this theory.

"Do the communication skills of secondary school students indirectly affect their addiction to computer games?" (Model-III)

According to the findings, the communication skills of secondary school students indirectly affect their addiction to computer games with the mediation of aggression. Inadequate communication skills of individuals cause aggression, and aggression causes gaming addiction. Therefore, insufficient communication skills trigger computer game addiction.

Communication skills are summarized as active listening to verbal and non-verbal messages and responding effectively (Erozkan, 2005). In addition, communication skills minimize possible attribution errors and misunderstandings by enabling individuals to communicate more openly and honestly (Kurtyllmaz, 2005). Therefore, it can be inferred that individuals who lack communication skills cannot express themselves accurately, clearly, and honestly; and that they are unable to evaluate verbal or nonverbal messages sent by other people properly; and that this situation may cause individuals to misunderstand or be misunderstood and bring interpersonal conflicts. Thus, an individual who is constantly in conflict with other people may think that others do not understand him; and may become hostile and aggressive towards them. Aggression also causes problems within interpersonal relationships (Odacı \& Berber Çelik, 2017). Therefore, it can be argued that individuals who 
do not have sufficient communication skills and who behave aggressively would become more and more lonely. Similarly, a study shows that individuals with inadequate communication skills have higher loneliness levels than others (Şahin, 1999). The individual, who is lonely because he cannot communicate well with people and does behave aggressively, may engage in computer games in his spare time when he is bored or wants to have fun since there is no one to spend time with. In short, individuals who do not have sufficient communication skills and have difficulty communicating with people with high levels of aggression can consider computer games as a friend, and games can replace the place of people over time. Individuals who become lonely do spend more time playing games (Horzum et al., 2018). This outcome of becoming addicted to games can be considered as an inevitable end for an individual who spends most of her/his day doing so.

When the relevant literature is examined, Grüsser et al. (2005) revealed that individuals who excessively play computer games are less willing to communicate, and their communication skills are less adequate than individuals who do not. However, it is not clear whether miscommunication causes excessive gaming or whether excessive gaming leads to miscommunication. Likewise, Karatekin et al. (2012) assert a significant negative relationship between the communication skills of secondary school students and the duration of computer use. In addition, Choi and Han (2006) found that the level of gaming addiction of children and adolescents is related to communication problems with their parents. Although these studies do not reveal a causal link, they support our research findings.

\section{Implications}

1- For children or adolescents to spend quality time, they can be guided to education or activities where they still would be intertwined with technology, apart from computer games.

2- Awareness-raising activities for students, parents, and teachers under the leadership of school psychological counselors can be implemented increasingly every year in direct proportion with the grade levels of the students.

3- With a tracking system that the parents can develop, gaming time can be controlled when the parents are away. 4- Studies can be conducted by parents, teachers, and school counselors to help children or adolescents gain time management skills.

5- Communication skills of children or adolescents can be improved so that they have increased healthy conduct of interpersonal relations.

6- Prevention studies can be carried out regarding the fact that aggressive children or adolescents are at risk of developing CGA.

7- Communication skills training can be provided to individuals addicted to computer games to improve their communication skills and reduce their level of CGA.

Future research directions:

Despite its limitations, the present study can lead to other important future investigations that will help better understand game addiction. For instance, future research should focus on the sub-dimensions of aggression (e.g., hostility, verbal aggression) and game addiction. It will also be beneficial to examine the specific mediators on the relationship between aggression, communication skills with game addiction among adolescents and other age groups.

\section{References}

Abay, E. \& Tuğlu, C. (2000). Șiddet ve agresyonun nörobiyolojisi. Klinik Psikiyatri, 3(21), 21-26. Retrieved from: https://www.journalagent.com

Aile ve Sosyal Politikalar Bakanlığı (ASPB). (2017, Ekim). Dijital oyunlar için çocuk ve aile rehberliği çalıştayı: Sonuç raporu. Retrieved from:

https://www.ailevecalisma.gov.tr/media/2496/dijital-oyunlar-icin-cocuk-ve-aile-rehberligi-calistayi-raporu.pdf.

Akçayır, G. (2013). Dijital oyunların sağlığa olumsuz etkisi. Ocak M. A. (Ed.), Eğitsel dijital oyunlar: Kuram, tasarım ve uygulama.(p. 69-104). Ankara: Pegem Akademi.

Aksakallı, G. (2017, 11 Ağustos). Dijital oyunların çocuklar ve gençler üzerindeki etkileri. Retrieved from: https://www.guvenliweb.org.tr/blog-detay/dijital-oyunlarin-cocuklar-ve-gencler-uzerindeki-

Allahverdipour, H., Bazargan, M., Farhadinasab, A. ve Moeini, B. (2010). Correlates of video games playing among adolescents in an Islamic country. BMC Public Health,10(1), 286. Retrieved from: https://bmcpublichealth.biomedcentral.com

Ayas, T. (2012). The relationship between Internet and computer game addiction level and shyness among high school students. Educational Sciences: Theory and Practice, 12(2), 632-636. Retrieved from: https://files.eric.ed.gov

Aydın, E. (2012). Üniversite öğrencilerinin boş zamanlarını değerlendirmeleri ile sosyal uyum ve iletişim becerileri arasındaki ilişkilerin incelenmesi (Master's Thesis). Retrieved from: YÖK Tez Merkezi (Thesis No: 321907).

Aydoğdu Karaaslan, İ. (2015). Dijital oyunlar ve dijital şiddet farkındalığı: ebeveyn ve çocuklar üzerinde yapılan 
karşılaştırmalı bir analiz. Uluslararası Sosyal Araştırmalar Dergisi, 8(36), 806-818. Retrieved from: https://web.a.ebscohost.com

Aziz, N., Nordin, M. J., Abdulkadir, S. J., \& Salih, M. M. M. (2021). Digital Addiction: Systematic Review of Computer Game Addiction Impact on Adolescent Physical Health. Electronics, 10(9), e996.

Balcı, M. \& Beldağ, A. (2019, October) Ortaokul ögrencilerinin saldırganlık algılarının çeşitli değişkenler açısından incelenmesi. 3. Uluslararası Eğitim ve Değerler Sempozyumu-ISOEVA, İstanbul.

Bağımlılık Tanı ve Tedavi Merkezi (BATEM) (16.06.2020). Bağımlılık Tedavileri Programları. Retrieved from: http://www.batem34.com/tedavi.asp

Choi, N. Y. \& Han, E. G. (2006). Predictors of children's and adolescents' game addiction: Impulsivity, communication with parents and expectation about the internet games. Journal of Korean Home Management Association, 24(2), 209-219. Retrieved from: https://www.koreascience.or.kr

Çankaya, İ. (2011). İlköğretimde akran zorbalığı.Uludă̆ Üniversitesi Eğitim Fakültesi Dergisi, 24(1), 81-92. Retrieved from: http://www.acarindex.com

Çelik, S. \& Ulusoy, B. (2019). Bilgisayar oyunlarının ortaokul öğrencilerinin sosyal yaşamına etkisi. The Journal of Social Science, 3(5), 46-60.

Dervent, F. (2007). Lise öğrencilerinin saldırganlık düzeyleri ve sportif aktivitelere katılımla ilişkisi. (Master's Thesis). Retrieved from YÖK Tez Merkezi (Thesis No: 205210).

Dill, K. E. \& Dill, J. C. (1998). Video game violence: A review of the empirical literature. Aggression and violent behavior, 3(4), 407-428.

Dumas, J. E., Blechman, E. A. \& Prinz, R. J. (1994). Aggressive children and effective communication. Aggressive Behavior, 20(5), 347-358. Retrieved from:

https://doi.org/10.1002/1098-2337(1994)20:5\%3C347

Emre, O. (2020). Effect of game addiction on reactive-proactive aggression in adolescents. Annals of Medical Research, 27(1), 85-91. doi: 10.5455/annalsmedres.2019.12.799

Erdoğdu, M. Y. \& Oto, R. (2004). Sokakta çalışan ve çalışmayan çocukların atılganlık ve saldırganlık davranışları açısından karşılaştırılmaları. Kriz Dergisi, 12(13), 11-23. Retrieved from:

https://dspace.ankara.edu.tr/xmlui

Ersanlı, K. \& Balcı, S. (1998). İletişim becerileri envanterinin geliştirilmesi: Geçerlik ve güvenirlik çalışması. Türk Psikolog Danışma ve Rehberlik Dergisi, 2(10), 7-12. Retrieved from:

https://toad.halileksi.net

Eroğlu, S. E. (2009). Saldırganlık davranışının boyutları ve ilişkili olduğu faktörler: lise ve üniversite ögrencileri üzerine karşılaștırmalı bir çalıșma. (Doctoral dissertation). Retrieved from YÖK Tez Merkezi (Thesis No: 235272).

Erözkan, A. (2005). Üniversite öğrencilerinin iletişim becerilerini etkileyen faktörler. Marmara Üniversitesi Atatürk Eğitim Fakültesi Eğitim Bilimleri Dergisi, 22, 135- 150. Retrieved from:

http://dspace.marmara.edu.tr

Ferguson, C. J. (2007). The good, the bad and the ugly: A meta-analytic review of positive and negative effects of violent video games. Psychiatric quarterly, 78(4), 309-316.

Griffiths, M. D. \& Dancaster, I. (1995). The effect of Type A personality on physiological arousal while playing computer games. Addictive behaviors, 20(4), 543-548

Griffiths, M. D., Davies, M. N. \& Chappell, D. (2004). Online computer gaming: a comparison of adolescent and adult gamers. Journal of adolescence, 27(1), 87-96.

Grüsser, S. M., Thalemann, R., Albrecht, U. \& Thalemann, C. N. (2005). Excessive computer usage in adolescents-a psychometric evaluation. Wiener Klinische Wochenschrift, 117(5-6), 188-195.

Hauge, M. R. \& Gentile, D. A. (2003, Nisan). Video game addiction among adolescents: Associations with academic performance and aggression. In Society for Research in Child Development Conference. Retrieved from: https://drdouglas.org

Horzum, M. B. (2011). İlköğretim öğrencilerinin bilgisayar oyunu bağımlılık düzeylerinin çeşitli değişkenlere göre incelenmesi. Ë̆itim ve Bilim, 36(159), 56-68. Retrieved from:

http://213.14.10.181/index.php/EB

Horzum, M. B., Ayas, T. \& Balta, Ö. Ç. (2008). Çocuklar için bilgisayar oyun bağımlılığı ölçeği. Türk Psikolojik Danışma ve Rehberlik Dergisi,3(30), 76-88.

Horzum, M. B., Güngören, Ö. C. \& Demir Kaymak, Z. (2018). Oyun bağımlılığı. Ayas, T. ve Horzum, M. B.(Ed.), Teknolojinin olumsuz etkileri. (p. 85-106). Ankara: Vizetek Yayınc1lık.

Jeong, E. J., Kim, D. J., Lee, D. M. \& Lee, H. R. (2016, January). A study of digital game addiction from aggression, loneliness and depression perspectives. 49. Hawaii International Conference On System Sciences (HICSS), Koloa.

Karatekin, K., Sönmez, Ö. F., \& Kuş, Z. (2012). İlköğretim öğrencilerinin iletişim becerilerinin çeşitli değişkenler açısından incelenmesi. Electronic Turkish Studies, 7(3), 1695-1708. Retrieved from: 
http://openaccess.ahievran.edu.tr/xmlui/handle/20.500.12513/513

Kestenbaum, G. I. \& Weinstein, L. (1985). Personality, psychopathology, and developmental issues in male adolescent video game use. Journal of the American academy of child psychiatry, 24(3), 329-333.

Kınay, B. (2019). Ergenlerde oyun bağımlılığının sosyal kaygı, saldırganlık ve sosyal dışlanma ile ilişkisinin incelenmesi. (Master's Thesis). Retrieved from YÖK Tez Merkezi (Thesis No: 542943).

Kim, C. N. \& Kwon, Y. H. (2004). The relationship between computer game addiction and the impulsiveness, aggression, and emotional intelligence of elementary school students. Journal of Korean Academy of Community Health Nursing, 15(3), 460-470. Retrieved from: https://www.koreascience.or.kr

Koç, B., Terzi, Y. \& Gül, A. (2015). Üniversite Öğrencilerinin İletişim Becerileri İle Kişilerarası Problem Çözme Becerileri Arasındaki İlişki. Uluslararası Türkçe Edebiyat Kültür Eğitim Dergisi, 4(1).369-390. Retrieved from: http://acikerisim.omu.edu.tr

Köksal, F. (1991). Denetim odă̆ ile saldırgan davranışlar arasındaki ilişkiler. (Doctoral dissertation). Retrieved from YÖK Tez Merkezi (Thesis No: 14511).

Kurtyılmaz, Y. (2005). Öğretmen adaylarının saldırganlık düzeyleri ile akademik başarıları, iletişim ve problem çözme bcerileri arasındaki ilişkiler:(Anadolu Üniversitesi ve Osmangazi Üniversitesi ögrencileri üzerinde bir araștırma). (Master's Thesis). Retrieved from YÖK Tez Merkezi (Thesis No: 187984).

Lemmens, J. S., Bushman, B. J. \& Konijn, E. A. (2006). The appeal of violent video games to lower educated aggressive adolescent boys from two countries. CyberPsychology \& Behavior, 9(5), 638-641.

McWhirter, J. \& Voltan Acar, N. (2000). Ergen ve çocukla iletişim. Ankara: Us-A Yayıncılık.

Odacı, H. \& Berber Çelik, Ç. (2017). Kendilik algısı ve saldırganlık arasındaki ilişki: yalnızlığın aracı rolü. Journal of Mood Disorders, 7(4), 219-25.

O' Rourke, K. \& Worzybyt, J. C. (1996). Support groups for children. USA: Brunner-Routledge.

Ögel, K. (2002). Băğımlılı̆̆ı önleme anne babalar öğretmenler için kılavuz. (2 ${ }^{\text {nd }}$ print). İstanbul: IQ kültürsanat yayıncılık.

Seay, A. F. \& Kraut, R. E. (2007, Nisan). Project massive: Self-regulation and problematic use of online gaming. In Proceedings of the SIGCHI conference on Human factors in computing systems, Montreal.

Setzer, V. W. \& Duckett, G. E. (1993). The risks to children using electronic games. Retrieved from: https://www.ime.usp.br

Şahin, R. (1999). The effect of the communication skills training program on children's loneliness and assertiveness level. (Unpublished master's thesis). Retrieved from YÖK Tez Merkezi (Thesis No: 82228).

Şahin, C. \& Tuğrul, V. M. (2012). İlköğretim öğrencilerinin bilgisayar oyunu bağımlılık düzeylerinin incelenmesi. Zeitschrift für die Welt der Türken/Journal of World of Turks,4(3), 115-130. Retrieved from: http://www.dieweltdertuerken.org

Tarhan, N. \& Nurmedov, S. (2017). Bağımlılık: Sanal veya gerçek. (5 $5^{\text {th }}$ print). İstanbul: Timaş Yayınları.

Tutgun Ünal, A., İnan, F., Tuğrul Kaya, M., Fırat, M., Güzelbaba, Z., \& Bahadır, A. (2013). Öğretmen Adaylarının Bilgisayar Oyunu Oynama Alışkanlıkları, Amaçları ve Oyun Tercihlerinin İncelenmesi: Maltepe Üniversitesi Örneği.AJIT-e: Online Academic Journal of Information Technology,4(12). $29-52$.

Wood, R. T. (2008a). A response to Blaszczynski, Griffiths and Turners' comments on the paper "problems with the concept of video game 'addiction': Some case study examples" (this issue). International Journal of Mental Health and Addiction, 6(2), 191-193.

Yalçın Irmak, A \& Erdoğan, S. (2016). Ergen ve genç erişkinlerde dijital oyun bağımlılı̆̆ı: güncel bir bakış. Türk Psikiyatri Dergisi, 27(2). 128-137.

Yeşilay. (2020). Teknoloji Bağımlılığı. Retrieved from: https://www.yesilay.org.tr

Yücel, M. T. (2002). Şiddet ve saldırganlık. Retrieved from: www.kriminoloji.com 